\title{
The Younger, the Better? A Multi-Factorial Approach to Understanding Age Effects on EFL Phonological Attainment
}

\author{
Zhengwei Pei \\ Nanjing Agricultural University \\ Correspondence concerning this article should be addressed to Zhengwei Pei, School of Foreign Studies, \\ Nanjing Agricultural University, 1 Weigang, Xuanwu District, Nanjing, Jiangsu 210095, P. R. China. \\ E-mail:wei@njau.edu.cn \\ Kerong Qin \\ Nanjing Agricultural University
Correspondence concerning this article should be addressed to Kerong Qin, School of Foreign Studies, Nanjing Agricultural University, 1 Weigang, Xuanwu District, Nanjing, Jiangsu 210095, P. R. China. \\ E-mail: 2014115005@njau.edu.cn
}

\begin{abstract}
Second language (L2) phonological acquisition is constrained by a complex interplay of extralinguistic factors, among which the age factor is frequently investigated. This study adopted a multi-factorial approach to examine the effects of the age of learning English (AoLE), along with ten other extra-linguistic factors, on the ultimate English phonological attainment of 318 university students in Chinese context for English as a foreign language (EFL) as a whole and across three cohorts: first-year non-English majors, first-year English majors, and third-year English majors. The participants were administered background questionnaires and receptive and productive EFL phonology tests. The results of regression analyses indicated that the AoLE was not a predictor for the whole sample, while English pronunciation self-concept (EPSC) turned out to be the most predictive. Predictors for each cohort varied in number and content. Whichever cohort the participants came from, EPSC remained a constant and potent predictor, whereas the AoLE could merely predict the phonological attainment of first-year non-English majors, accounting for $4 \%$ of its variance. The findings of the study contribute to the longstanding debate over the viability of the critical period hypothesis, provide methodological implications for age-related L2 phonology research, and inform early EFL educational decisions.
\end{abstract}

Keywords: age of learning English, multi-factorial approach, Chinese EFL context, phonological attainment, university students

\section{Introduction}

Second language (L2) phonological acquisition is constrained by a complex interplay of extra-linguistic factors, which refer to "personal, environmental, and instructional variables within the learner rather than those stemming from differences between two language systems" (Jacobsen \& Imhoof, 1974, p. 329). Among these factors, age of acquisition has received considerable attention in the English as a second language (ESL) context. Generally, older learners initially acquire the L2 faster than younger ones (older is better for rate of acquisition), but younger starters will be superior in terms of ultimate attainment (younger is better in the long run) (Krashen et al., 1979). Over the past few decades, a sizable amount of age-related literature has highlighted ultimate attainment, whether it be native-like attainment or any other outcome, because evidence from the end state determines the upper limits of L2 attainment and the explanation of outcome differences is of fundamental importance for L2 theory construction (Birdsong, 2006; Long, 2007). Research findings consistently demonstrate a negative correlation between age of acquisition and L2 ultimate attainment, namely, younger onset is associated with better attainment, in particular for phonology (Abrahamsson, 2012; Birdsong, 2006; Moyer, 2014). 
The notion of 'younger is better' relates to the critical period hypothesis (CPH). The strongest evidence for this hypothesis comes from the study of L2 phonology, where older learners seldom achieve the native-like accent that younger ones display due to their lost neural plasticity over the critical period, its cutoff roughly coinciding with puberty (Doughty \& Long, 2003; Lenneberg, 1967). The worldwide advocacy for early foreign language (FL) courses is strongly influenced by the $\mathrm{CPH}$ and 'younger is better' notion. Polish publications for language teachers, for instance, usually recommend an early start in FL instruction, centering mostly on phonetic aspects of the CPH (Singleton \& Leśniewska, 2012). A survey of over thirty countries in Europe and Asia revealed that almost all of the countries required children to learn English as a foreign language (EFL) subject at primary school with the aim of a higher level of proficiency (Yoleri \& Yatağanbaba, 2013).

Then is younger always better? Although accumulated evidence from immigrant research of naturalistic L2 acquisition has profiled a tendency for long-term benefits on the part of younger starters, studies conducted in formal instructional settings do not seem to testify to younger learners' advantage over seniors in the long run (Singleton \& Muñoz, 2011; Singleton \& Skrzypek, 2014). Age effects may be moderated by the learning context. FL learning tends to favor older learners endowed with superior cognitive skills and better explicit learning, and places younger learners at a disadvantage, since the input-impoverished context impedes the implicit learning at which they may be superior (Muñoz, 2008). The FL learning context involves classroombased learning without societal structures for the L2 use, thus explicit learning is emphasized-a strength for older learners, while implicit learning is disabled-the strength of younger learners.

Given that the age effects in FL settings partially differ from those in naturalistic settings, and that FL studies are far from adequate for unveiling how starting ages influence outcomes of FL learning, as noted by Muñoz (2008), the present study attempts to ascertain whether 'the younger the better' holds true in the Chinese EFL context. It examines the effects of age of learning English (AoLE) along with ten other extra-linguistic factors on the ultimate EFL phonological attainment (EPA) of university students in China via a multi-factorial approach, an approach necessary for studies of age-related effects to elucidate the dynamic interaction of multiple factors in L2 phonological acquisition (Gui, 2012; Moyer, 2014; Singleton \& Muñoz, 2011).

The university students involved are classified according to their major and grade to see the age effects across three cohorts, i.e., first-year non-English majors, first-year English majors, and third-year English majors. The ten factors include gender (Gen), aptitude for oral mimicry (AOM), musical ability (MuAb), amount of oral English use (AOEU), amount of English phonological training (AEPT), experiences with other foreign languages (EoFL), personality (Pers), English pronunciation self-concept (EPSC), motivation for English phonology learning (MEPL), and strategies for English phonology learning (SEPL). These factors were selected because they are possible predictors of L2/FL phonology from previous studies as well as their applicability to the Chinese EFL context. For example, in their review study Piske et al. (2001) singled out the variables frequently claimed to influence the degree of L2 foreign accent. Apart from age of L2 learning, other variables are gender, motivation, language learning aptitude (musical ability, mimicry ability), amount of L2 use, length of residence in an L2-speaking country, and formal instruction in the L2. In explaining why some late learners exhibit exceptionally successful outcomes in L2 phonology, Moyer (2014) examined the cognitive, social, psychological and experiential factors that co-vary with age, such as strategies, personality, and self-concept. All of those variables were considered in the present study except for the length of residence due to its inapplicability to Chinese EFL learners. In Elliott (1995), the number of foreign languages other than the target language under study was surveyed to determine whether rich language learning experiences would play a facilitative role in mastering pronunciation of the target language. Given that EFL learners in China may have had contact with foreign languages other than English, this variable was also subsumed into the study.

\section{Research Questions}

Two research questions were addressed:

1. To what extent can age of learning English and ten other extra-linguistic factors predict the English phonological attainment of university students in the Chinese EFL context?

2. Does the predictability of these factors vary across three cohorts depending on students' majors (nonEnglish vs. English) and year in school (freshmen vs. juniors)? 
English phonological attainment is operationalized as the performance of receptive and productive phonology in English, both on the segmental and suprasegmental levels.

\section{Materials and Methods}

\section{Participants}

A total of 318 undergraduates from three state-owned universities in Nanjing, China constituted the sample for this study. They all filled out questionnaires and completed tests on receptive and productive EFL phonology (see the next section for details). They came from 20 different classes and represented a sample of convenience. They had intact hearing and were between 18 and 23 years of age (mean =19.7). Of the sample, $235(73.9 \%)$ were female and 83 (26.1\%) male, reflecting a preponderance of girls in most mainland Chinese universities. They were distributed across three cohorts: 134 (42.1\%) first-year non-English majors specializing in finance, land management, computer science, clinical medicine, mathematics, etc., 97 (30.5\%) first-year English majors, and 87 (27.4\%) third-year English majors.

Our participants were at least 18. They started formal English education in Grade 3 of primary school, as stipulated by the Ministry of Education (MoE) of China, and experienced about 10 years of English study. This time period should be long enough for advantages, if any, to emerge. That being said, the participants were continuing to study English at college and may not have reached their point of ultimate attainment.

\section{Procedure and Instruments}

The study was carried out with data collected over two sessions. In the first session, which lasted about 30 minutes, participants answered the background questionnaire and took the receptive EFL phonology test in a sound lab or multimedia room during class time. In the second session, they individually accomplished the productive EFL phonology test after class.

Background Questionnaire. The questionnaire, in addition to querying demographic information such as name, chronological age, major, grade, university, and hearing status, elicited data pertinent to the 11 surveyed factors. It was composed of five parts and given in Chinese. See Appendix One for Chinese and English versions of the questionnaire.

Part One is directed at seven factors encompassing AoLE, Gen, EoFL, AOM, MuAb, AOEU, and AEPT. The participants supplied their data on AoLE (the age at which they began to learn English), Gen, and EoEL (whether they had learned or picked up foreign languages other than English). Then they self-rated their AOM on a 5 -point scale, ranging from 1 (extremely weak) to 5 (extremely strong). Their self-ratings in musicality and singing on a similar scale were averaged to signify their degrees of MuAb. With regard to AOEU, participants estimated the total hours that they orally use English in and outside of English class per week at the time of taking part in this study. As for AEPT, they estimated how long they had received English phonological training from regular classes at school or/and extracurricular programs before they participated in the study.

Part Two tests personality (Pers) with a focus on the introversion-extroversion dimension. To this end, a Chinese version of the Eysenck Personality Questionnaire, revised by Chen (1983) and shown to be of high validity and reliability for Chinese adults (Qian et al., 2000), was employed. This part comprises 21 Yes/No questions. For positively worded questions (e.g., Are you talkative?), one score was assigned to each Yes answer, whereas for reverse worded questions (e.g., Do you always keep silent when you are together with others?), one score was given to each No answer. The higher the total score, the more extroverted the participant was inclined to be. The part also subsumes seven distracting questions irrelevant to personality and intended for detecting response defensiveness and ensuring the validity of the given answers; a participant giving more than six No answers was excluded and their answers considered invalid.

Part Three concerns EPSC, which is defined as the learner's self-conception and assessment of his or her English pronunciation proficiency (Tang et al., 2013). Patterned after Mu's (2006) questionnaire for Chinese university students, it contains eight items, five of which are positively worded (e.g., My English pronunciation is pleasant 
to others' ears.) and the rest negatively worded (e.g., My English pronunciation is poor.). After each item is a 5 -point rating scale to choose from $(1=$ never or almost never true of me, $5=$ completely or almost completely true of me). The negatively worded items were later reverse scored.

Parts Four and Five measure participants' MEPL and SEPL. Motivation refers to a combination of the learner's attitudes, aspirations, and effort with respect to L2 learning (Dörnyei \& Schmidt, 2001). The 15 motivation items are derived from Pei (2010) and grouped into four categories: attitude towards English phonology learning (e.g., A mastery of good pronunciation is important in English study.), concern for English pronunciation (e.g., I will study hard to perfect my English pronunciation.), integrative motivation (e.g., I take a keen interest in English and the cultures of English-speaking communities), and instrumental motivation (e.g., Being able to speak English helps with job hunting.). Pronunciation learning strategies are defined as the steps utilized by students to enhance their pronunciation learning (Peterson, 2000). The 37 strategy items are adapted from Peterson's questionnaire. They fall into five categories: meta-cognitive strategies (e.g., record oneself to listen to one's pronunciation), cognitive strategies (e.g., repeat aloud after a native speaker or teacher), memory strategies (e.g., make up songs or rhythms to remember how to pronounce words), affective strategies (e.g., use a sense of humor about mispronunciations), and social strategies (e.g., ask someone else to correct one's pronunciation). Each item, motivational or strategic, is followed with scalar ratings from 1 (never or almost never true of me) to 5 (completely or almost completely true of me).

The calculated Cronbach's Alpha coefficients for Parts Two, Three, Four and Five using SPSS 16.0 were respectively $.836, .913, .905$, and .890 , indicative of satisfactory internal consistencies and the reliability of these parts.

Receptive EFL Phonology Test. Receptive phonology was tested on segmental (phoneme) and suprasegmental (rhythm and intonation) levels. Participants first heard a prerecorded list of 39 items targeting twenty-two consonants and sixteen vowels. Each item comprises word triplets $A-B-X$ (not printed on the answer sheet to avoid phoneme-grapheme mapping cues). $A$ and $B$ make up a minimal pair, with $X$ from the same phonemic category as either $A$ or $B$ (e.g., teeth-teethe-breath, seal-zeal-zip). $A, B$, and $X$ contain an equal number of phonemes and the contrastive phoneme in them occupies the same initial, medial, or final place. Participants were asked to determine whether $X$ was phonemically identical to $A$ or $B$. Afterwards, they heard 11 rhythm items covering seven rhythmic patterns where $S$ and $w$ represent stressed and unstressed syllables (e.g., SwS, wSwS). While hearing paired phrases in each item, they determined whether the rhythmic patterns were identical (e.g., WORD by WORD-HARD and FAST) or not (e.g., LOTS to be DONE-our TIME is UP). The phrases are of the same number of monosyllabic words and in a declarative form. Finally, participants heard 10 intonation items in four simple (e.g., fall or rise) and six combined (e.g., fall + rise, fall + fall) intonation patterns. They decided whether paired sentences within each item were the same (e.g., He was right,/nevertheless.[fall/rise]-You're wrong,/actually.[fall/rise]) or different (e.g., Have you time?[rise]-I am not sure. [fall]).

The stimulus words, phrases, and sentences were taken from Zhang (1988); their matching audio files were extracted and spliced together with a seven-second pause inserted between every other item. The participants heard everything only one time before making their choices on the answer sheet.

Productive EFL Phonology Test. Productive phonology was assessed through a passage-reading task to reflect participants' segmental and suprasegmental abilities. The passage, used by Luo and Zhang (2006), is 141 words long with a wide coverage of twenty-one consonants and sixteen vowels, among which are challenging phonemes for Chinese students to articulate (e.g., /n/ vs. /l/,/v/vs. /w/). It also contains words whose stress placement can easily confuse students (e.g., excellent), and sentences with varied intonations. For example, intonation should rise after skin and rim in the sentence 'you will see that the potato has a skin, an outside rim, and an inside part', but more than 2/3 of the university students Luo and Zhang (2006) tested took no notice of it.

Participants were each asked to read the passage at a normal speed after class, record their readings, and save in mp3 or wma format. Before submission, they checked the saved recordings to guarantee their clarity.

\section{Scoring of EFL Phonology Tests}

Participants' answer sheets to the receptive phonology test were manually scored by the first author, a correct 
segmental or suprasegmental answer awarded 0.5 points or 1 point. Their readings on the productive phonology test were randomly mixed and then rated by two second-year MA graduate students of applied linguistics, both having taught non-English majors for one year, on a 5-point scale $(3,6,9,12,15)$ for segmental precision and suprasegmental native-likeness. On the segmental level, the raters evaluated the accuracy with which the participant pronounced English sounds, assigning a rating in light of the number of mispronounced phonemes ( $3=7$ or more than 7 phonemes mispronounced, $6=5-6$ phonemes mispronounced, $9=3-4$ phonemes mispronounced, $12=1-2$ phonemes mispronounced, $15=$ no phoneme mispronounced). On the suprasegmental level, they rated on a similar scale from 3 (not at all native-like) to 15 (native-like) based on how the participant was native-like in aspects of rhythm, stress, and intonation. After scoring, inter-rater reliability was calculated, and Cronbach's Alpha coefficients were .858 for segmental production and .854 for suprasegmental production, implying a substantial inter-rater agreement. Then the ratings from two raters were averaged; the resulting mean for productive phonology was combined with the score for receptive phonology to produce a composite score for each participant representing his or her EPA. Since the full marks for the receptive and productive phonology tests were 40.5 and 30 , the maximum score was 70.5 .

\section{Statistical Analysis}

First, a descriptive analysis was performed on the 11 factors (predictors) and EPA phonology test scores (dependent variable) (SPSS 16.0; See Table 1). Next, a correlational analysis was used to assess the relationships between each predictor and EPA. Finally, a series of regression analyses was run to identify which predictors could significantly influence EPA of the whole sample of students and to compare their predictive powers across the three cohorts. The results of the regressions were used to answer the research questions. Note that in answering the second question, we randomly selected an equal number $(\mathrm{n}=80)$ of students from each cohort, but ensured the same percentage of males therein $(n=9,11.2 \%)$ to eliminate the possible disturbance of gender imbalance.

Table 1

Descriptive Statistics for 11 Predictors and the Dependent Variable

\begin{tabular}{|c|c|c|c|c|c|c|}
\hline Predictors/ dependent variable & Mean & SD & Range & & Data source & \\
\hline AoLE & 8.92 & 2.30 & $3-14$ & in years & \multirow{7}{*}{ Part 1} & \multirow{11}{*}{$\begin{array}{l}\text { background } \\
\text { questionnaire }\end{array}$} \\
\hline Gen & 1.74 & .44 & $1-2$ & male: 1 ; female: 2 & & \\
\hline EoFL & 1.41 & .49 & $1-2$ & no: 1 ; yes: 2 & & \\
\hline $\mathrm{AOM}$ & 3.19 & .66 & $1-5$ & ratings on & & \\
\hline $\mathrm{MuAb}$ & 3.03 & .85 & $1-5$ & a 5-point scale & & \\
\hline AOEU & 2.49 & 2.81 & $0-16.7$ & \multirow{2}{*}{ in hours } & & \\
\hline AEPT & 54.08 & 113.16 & $0-675$ & & & \\
\hline Pers & 10.39 & 4.84 & $1-20$ & scores & Part 2 & \\
\hline EPSC & 26.08 & 6.37 & $8-40$ & \multirow{3}{*}{$\begin{array}{l}\text { ratings on } \\
\text { a 5-point scale }\end{array}$} & Part 3 & \\
\hline MEPL & 60.09 & 8.79 & $32-75$ & & Part 4 & \\
\hline SEPL & 119.53 & 17.73 & $54-181$ & & Part 5 & \\
\hline EPA & 49.08 & 7.10 & $21-64.5$ & \multicolumn{3}{|c|}{ scores on receptive/productive phonology tests } \\
\hline
\end{tabular}

\section{Results}

\section{Predictors for EFL Phonological Attainment from the Whole Sample}

The 11 predictors and dependent variable were divided into three types in accordance with their levels of measurement. Gen and EoFL were binary nominal variables; AOM, MuAb, EPSC, MEPL, and SEPL were ordinal; AoLE, AOEU, AEPT, Pers, and EPA were interval. As a preliminary check of data normality, skewness and kurtosis values were computed. All the values were within the accepted ranges (skewness: -1.094 to 2.325; kurtosis: -1.883 to 6.303) except those for AEPT (skewness: 3.277; kurtosis: 11.034), an absolute skew value greater than 3 or an absolute kurtosis larger than 8 having been used as reference values for determining substantial nonnormality (Kline, 2005). 
We then analyzed the bivariate associations between each predictor and EPA with Pearson's, Spearman's, and point-biserial correlations, depending on the types of variables involved and whether data were normally distributed. Pearson's correlation was performed between two interval variables or between an interval dependent variable and an ordinal predictor with more than two categories, and point-biserial correlation was performed between an interval dependent variable and a binary nominal predictor (De Vaus, 2002; Kline, 2005). The strength of association between EPA and AEPT was tested with Spearman's rank order correlation, because of the non-normal distribution of AEPT noted above. Appendix Two attaches the correlations among the predictors and EPA.

As reported in Table 2, except for Pers, other predictors were significantly correlated with EPA at the .01 or .001 level. Among the significant correlates, only AoLE produced a negative correlation $(r=-.146)$, seemingly upholding the CPH for L2 phonological acquisition and the notion of 'younger is better'. The most noticeable correlation existed between EPSC and EPA $(\mathrm{r}=.483)$.

Table 2

Bivariate Correlations between the Predictors and EFL Phonological Attainment (EPA)

\begin{tabular}{|c|c|c|}
\hline Predictors & Correlation with EPA & Sig. (2-tailed) \\
\hline Age of learning English (AoLE) & $-.146^{m * a}$ & .009 \\
\hline Aptitude for oral mimicry (AOM) & $.224^{* * n a}$ & .000 \\
\hline Musical ability (MuAb) & $.294^{* n+a} \mathrm{a}$ & .000 \\
\hline Amount of oral English use (AOEU) & $.208^{n+s * a}$ & .000 \\
\hline Personality (Pers) & $.003^{\mathrm{a}}$ & .962 \\
\hline English pronunciation self-concept (EPSC) & $.483^{* n w^{*} a}$ & .000 \\
\hline Motivation for English phonology learning (MEPL) & $.319^{m * n a}$ & .000 \\
\hline Strategies for English phonology learning (SEPL) & $.263^{\operatorname{mos} a} a$ & .000 \\
\hline Amount of English phonological training (AEPT) & $.292^{n * m b}$ & .000 \\
\hline Gender (Gen) & $.253^{*+\cdots+c}$ & .000 \\
\hline Experiences with other foreign languages (EoFL) & $.240^{* * n+k} \mathrm{c}$ & .000 \\
\hline
\end{tabular}

Note. ${ }^{* * *} \mathrm{p}<.01,{ }^{* * * *} \mathrm{p}<.001$ (2-tailed)

Correlation computed as aearson's r, b Spearman's rho, c point-biserial $\mathrm{r}_{\mathrm{pb}}$

To test whether the correlated relations persisted when controlling for other variables, the ten significant correlates were submitted for stepwise regression analysis. Prior to that, we created dummy variables for Gen and EoFL so that 'male' and 'no' (without such experiences) were recoded as 0, whereas 'female' and 'yes' (with such experiences) were recoded as 1 . For a regression we did not look at the distribution of individual variables but instead at the distribution of the residuals. Multivariate normality can be examined via a P-P plot (LarsonHall, 2010). The P-P plot of the standardized residuals was essentially linear on the $45^{\circ}$ line, revealing data to be normally distributed. No multicollinearity between predictors was detected judging from collinearity statistics of Tolerance and VIF (variance inflation factor). The assumptions for regression were met.

The order of entering the predictors into the regression depended on their statistical contribution in explaining the variation in the dependent variable. The criterion when entering predictors was a probability of F-change $<.05$. As a result, all but five predictors (EPSC, Gen, AOEU, EoFL, and MEPL) were excluded as they did not contribute significantly to the probability of F-change. These five predictors were able to jointly account for $31.4 \%$ of the variance in EPA (Table 3). Although AoLE was significantly correlated with the EPA of the whole sample of students, it failed to enter the model, and was unable to produce any effect.

EPSC was entered first into the model, significantly accounting for $23.3 \%$ of the variance. The other four predictors were entered in Steps 2, 3, 4, and 5 respectively, explaining the additional $4.2 \%, 2 \%, 1 \%$ and $0.9 \%$ of the variance. EPSC was by far the most important predictor, accounting for more variance than any other predictor. A comparison of the final (post-step 5) standardized beta weights further stressed its predictive power and unique contribution for explaining EFL phonological variance, with the largest beta weight ( $\$=$ $.414, \mathrm{p}=.000$ ). The beta coefficients for Gen and EoFL were both positive. Since we had chosen 'male' and 'no' as the comparison category, the beta coefficient for the female dummy variable was .115, suggesting that on 
Table 3

Regression Model on EPA and Its Predictors

\begin{tabular}{|c|c|c|c|c|c|c|c|}
\hline Step & Predictors & $\mathbf{R}$ & R square $^{a}$ & $R_{\text {square change }}{ }^{b}$ & F value $^{\mathrm{c}}$ & Prob. $^{d}$ & Final Beta ${ }^{e}$ \\
\hline 1 & EPSC & .483 & .233 & .233 & $96.058^{k, w a x}$ & .000 & $.414^{\operatorname{mos} m}$ \\
\hline 2 & Gen & .524 & .275 & .042 & $59.632^{* \cdots * * x}$ & .000 & $.115^{\prime \prime}$ \\
\hline 3 & AOEU & .543 & .295 & .020 & $43.801^{\text {sosen }}$ & .000 & $.119^{*}$ \\
\hline 4 & EoFL & .552 & .305 & .010 & $34.298^{* * n+k}$ & .000 & $.109^{*}$ \\
\hline 5 & MEPL & .560 & .314 & .009 & $28.516^{\text {sestax }}$ & .000 & $.107^{*}$ \\
\hline
\end{tabular}

Note." $\mathrm{p}<.05,{ }^{* * * * ⿲} \mathrm{p}<.001$

a Cumulative variance accounted for at each step

${ }^{\mathrm{b}}$ Increase in variance from the preceding step

${ }^{\mathrm{c}} \mathrm{F}$ value testing the significance at each step

${ }^{\mathrm{d}}$ Probability that adding the last predictor accounted for significantly more variance

e Standardized beta weight for each predictor when controlling all other predictors

average, being female, as compared with being male, increased a participant's EFL phonological score by .115 points. Similarly, on average having learned or picked up other foreign languages, compared to its counterpart, increased a participant's phonological score by .109 .

\section{Predictors for EFL Phonological Attainment across Three Cohorts}

To have a complete comparison of the relative effects of AoLE and ten other factors on the EPA of different groups of university students, we followed the same procedure to perform regression analyses repeatedly across the three cohorts. The results (Table 4) indicated that the three models vary in the number and inclusion of predictors.

Table 4

Model Summaries of the Predictability of EPA Across Three Cohorts

\begin{tabular}{|c|c|c|c|c|c|c|c|}
\hline Step & Predictors & $\mathbf{R}$ & R square $^{a}$ & $R_{\text {square change }}{ }^{b}$ & F value ${ }^{c}$ & Prob. $^{d}$ & Final Beta ${ }^{e}$ \\
\hline \multicolumn{8}{|c|}{ For first-year non-English majors } \\
\hline 1 & EPSC & .501 & .251 & .251 & $26.204^{\text {kson }}$ & .000 & $.362^{* w n k x}$ \\
\hline 2 & MEPL & .590 & .348 & .097 & $20.568^{* * * * n}$ & .000 & $.335^{* * *}$ \\
\hline 3 & AoLE & .623 & .388 & .040 & $16.093^{* * a+}$ & .000 & $-.201^{* \prime}$ \\
\hline \multicolumn{8}{|c|}{ For first-year English majors } \\
\hline 1 & EPSC & .485 & .235 & .235 & $23.943^{\text {nown }}$ & .000 & $.455^{m+w a n}$ \\
\hline 2 & Gen & .543 & .295 & .060 & $16.126^{\text {wask }}$ & .000 & $.247^{\prime \prime}$ \\
\hline \multicolumn{8}{|c|}{ For third-year English majors } \\
\hline 1 & EPSC & .344 & .118 & .118 & $10.449^{* * n}$ & .002 & $.349^{k n+1}$ \\
\hline 2 & AOEU & .432 & .186 & .068 & $8.820^{\text {mana }}$ & .000 & $.261^{*}$ \\
\hline
\end{tabular}

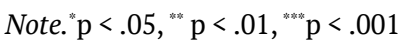

The model with the three predictors could explain about 39\% of the variance in first-year non-English majors' EFL phonology test scores. The two-predictor model for first-year English majors accounted for roughly 30\% of the variance. For third-year English majors, two predictors explained about 19\% of the variance. No matter which cohort the participants were from, EPSC turned out to be a constant and potent predictor. AoLE merely entered the model for first-year non-English majors, explaining $4 \%$ of the variance. Besides the age factor, MEPL was also explanatory. As the year in school of English majors went up from freshmen to juniors, AOEU replaced Gen as another predictor aside from EPSC.

Admittedly, there are many studies scrutinizing the effects of one or a couple of extra-linguistic factors on L2 phonology, but just a few have adopted a multi-factorial approach to investigate multiple factors in the ESL context. Even fewer studies have so far been conducted in the EFL context. An early study by Thompson (1991) examined the influence of 18 factors on 36 Russian immigrants' ESL pronunciation. The resulting model 
included age of arrival in the U.S., gender, ability to mimic, and global English speaking proficiency, explaining $67 \%$ of the variance in pronunciation accuracy. Other factors such as musical ability, L2 use, extroversion, and use of pronunciation strategies produced no apparent effect. Sheppard et al. (2007) assessed 26 factors in an attempt to decide which of them were responsible for variations in the EFL pronunciation of 67 Japanese university students. The predictive factors covered musical ability, attitudes towards pronunciation learning, length of time spent on English study, and strategy use; they combined to explain 32\% of the variance.

The few available studies have determined the relative contributions of a variety of factors to English phonology by applying regression analysis, but they are restricted to productive phonology alone and their sample sizes are rather small. To advance this line of inquiry, we explored the impact of AoLE and ten other factors on the EFL phonological attainment of 318 university students via a multi-factorial approach, with phonology measured both receptively and productively. For a comparative purpose, three cohorts of students in different majors and grades were further selected to see whether their phonological attainments were affected by differing factors. It was found that for the whole sample, five predictors jointly accounted for $31.4 \%$ of the variance in EFL phonological scores. EPSC was most predictive, while AoLE was not a predictor. Across the three cohorts, EPSC was a constant and robust predictor, but AoLE could only predict the phonological attainment of first-year non-English majors.

\section{Discussion}

Our discussion will center around AoLE and EPSC on account of their thematic relevance and statistical significance.

\section{On Age of Learning English}

AoLE in this study was significantly and negatively correlated with the EPA of the whole sample, but could not predict it. It could predict the EPA of first-year non-English majors, explaining $4 \%$ of its variance; however, it accounted for less of the variance than two other predictors, namely, EPSC and MEPL.

This study is the first made in China, even in Asia, to inspect AoLE in conjunction with multiple factors by regression analysis, thus its findings are seemingly incomparable to that of any prior research. Two studies utilizing disparate statistical methods have surveyed the long-term age effect in Asian EFL contexts. To examine the age effect on ultimate EFL phonological attainment of Japanese college students, Larson-Hall (2008) compared those who started studying English between ages 3 and $12(n=61)$ with counterparts who began their studies at age 12 or $13(n=139)$. The earlier starters were found to score statistically higher on the receptive phonological measure, and this remained true in an ANCOVA analysis where total hours of input were controlled for. Pei (2012) looked at the impact of age of learning English on the EFL phonological performance of 155 first-year non-English majors in a Chinese university. A one-way ANOVA analysis demonstrates that an earlier start results in higher phonology scores. Her participants were freshmen non-English majors whose phonology was measured receptively and productively, analogous to the cohort of first-year non-English majors participating in the present study. In some ways, the findings of our study partially coincide with what the two studies reported. The age of learning English does play a role in predicting the EFL phonological attainment of freshmen non-English majors within the Chinese EFL context, but its explanatory power is relatively weak, and certainly not as strong as it has shown to be in an ESL context.

During the past three decades, one remarkable change in English education within China is the lowering of the starting age of English learning and the expansion of English education into primary schools (Zhang, 2012). English has been a compulsory subject from secondary schools to universities since 1978 and, spurred by the 'younger is better' belief, further expanded to primary schools in January 2001. That year, the MoE issued a FL educational policy mandating that primary schools located in cities and county seats start to offer English classes at primary school third graders from the autumn of 2001 and the rest began to do so in the following year $(\mathrm{Hu}, 2005)$. Although earlier English education is not enforced, preschoolers in socioeconomically advantaged regions are always sent by their parents to English courses given by kindergartens, nurseries, or out-of-school language institutions to gain a competitive edge. In Beijing, a renowned English educational school primarily 
enrolling students aged between 3 and 14 witnessed an increase in enrollment of $30 \%$ every year. ${ }^{1}$

The belief that an earlier start is more beneficial to English learning takes shape based on research findings in the L2 context that there is a critical period of FL learning. Its popularity may have influenced the decision making of the MoE. Starting English education at primary school is meant to satisfy China's need for proficient English users and parents' wishes for upward social, economic, and professional mobility for their children, however EFL educators, researchers, and teachers have questioned the feasibility of this early-start policy. Despite much improvement in the infrastructure for English language education in China, the implementation of the policy in primary schools nationwide is still fraught with problems and the major one is a shortage of qualified teachers (Hu, 2005; Zhang, 2012). The quality of primary school English teachers in China is by no means optimistic, not only in economically less-developed regions, but also in economically well-developed regions (cf. Zhang, 2012). As a prestigious EFL educationalist and linguist in China, Gui (2012) also notes the inadequacy of the professional English teaching force in the public school system and out-of-school private sectors, and warns against the frantic pursuit of learning English as early as possible. Unqualified local teachers or recruited foreign teachers may not provide standard pronunciation or be acquainted with English phonology teaching methods, thereby actually becoming detrimental to young learners' acquisition of EFL phonology. Effective early FL instruction is incredibly reliant on the availability of well-trained and professionally competent teachers. After reviewing recent advances in theories and practice concerning the age factor in English education, Gui (2012) called for age-related empirical studies conducted via a multi-factorial approach to inform our language educational decisions.

In this study, we took the initiative to investigate the age factor using a multi-factorial approach, and our findings seem to dispel the myth of the early start. 'The younger the better' does not completely hold true for the Chinese EFL context. Given the lack of qualified teaching faculty in China, EFL education earlier than the third grade of primary school is not so necessary and has to be approached with caution.

\section{On English Pronunciation Self-Concept}

As a hierarchical and multifaceted model, self-concept is categorized into academic and non-academic selfconcept. English self-concept falls into the academic category and embraces specific dimensions, one of which is the English pronunciation self-concept.

Self-concept has been found to be positively linked to key psychological factors and learning outcomes, such as interest, motivation, persistence, strategy use, and self-regulated learning, and it plays a decisive role in successful learning (Mercer, 2012). Nonetheless, there remains little research into self-concept within L2 acquisition and FL learning and less exclusively into EPSC in the EFL context. To the best of our knowledge, two pertinent studies exist. Wang (2004) in China reports on an inquiry into the relationship between EPSC and the actual EFL pronunciation of 45 junior high school students, discovering that EPSC was significantly related to pronunciation (Pearson's $\mathrm{r}=.54, \mathrm{p}<.01$ ). In Poland, Jedynak (2013) investigated 30 undergraduates of the English Philology Department at Wrocław University on measures of EPSC, a self-concept questionnaire, and final attainment in EFL pronunciation, a five-sentence reading task. She classified participants into either positive, medium, or negative self-concept learners corresponding to the intensity of their self-concept development, obtaining a significant correlation between EPSC results and pronunciation ratings (Spearman's rho $=.37, \mathrm{p}=.046$ ). The present study resonates with the aforementioned studies and goes one step further by adopting a multi-factorial approach. Compared with the age factor, pronunciation self-concept is a much more robust predictor of the EFL phonological attainment of the whole sample as well as of the three cohorts of Chinese university students, regardless of their major and grade, explaining $11.8-25.1 \%$ of the variance in phonological scores.

Several pioneering studies explored the extent to which self-concept is stable or malleable; their results support research findings elsewhere, i.e., a learner's self-concept can at once be relatively stable and dynamic (Mercer, 2012). Mercer $(2011 ; 2012)$ examined the nature and development of female university learners' self-concepts in the Austrian EFL context, with data generated within the framework of a longitudinal case study using journals and interviews. The findings point to both stable and dynamic elements in relation to the learners' self-concept.

\footnotetext{
1 Jin, H. T., \& Du, B. (2013, October 17). Four questions on the rush of children’s English learning. Guang Ming Daily.
} 
Likewise, King and McInerney's (2014) longitudinal study testifies to the dynamicness and malleability of selfconcept. In their study, English self-concept was measured thrice across three years among 2618 students from 16 secondary schools in Hong Kong. The results indicated that students' English self-concept slightly increased over time. Students may become more confident about their ESL abilities as they progress through higher educational levels, thus the increase in English self-concept resulted.

Self-concept is formed through experience with and interpretations of one's environment, especially influenced by evaluations from significant others (Marsh \& Shavelson, 1985). According to Festinger's (1954) social comparison theory, people use significant others in their environment as frames of reference in forming self-assessments. The influential factors contributing to the development of self-concept relate to home and school; parents, siblings, teachers, and peers naturally function as significant others (Alrajhi \& Aldhafri, 2015). Significant others are also part of the language learning process. For social constructivists, learning takes place in a certain social context through interactions with others; language learning in classroom settings is primarily composed of interactions with language teachers and classmates. Accordingly, teachers and fellow students are the most important significant others in the formation of language learners' self-concepts. In school, teachers can greatly impact students' self-concepts through their teaching practices and close relationships with students; peers can also do this via peer scaffolding and establishing a rapport with one another.

EFL phonology learning not only involves the imitation of phonetic symbols or a sensitivity to prosodic variations, but also concerns learners' self-perceptions of their pronunciation abilities. Maintaining a positive English pronunciation self-concept is crucial in helping students to reduce anxiety, boost confidence and interest in orally using English, and therefore improve their EFL phonological performance. The present study demonstrates a non-negligible predictability of EPSC. Considering that certain aspects of self-concept are dynamic, English teachers can play a role in molding student self-concept, especially in Asian EFL contexts where learners nurtured by the traditional Confucian culture are liable to view their teachers as an authority figure. Teachers are advised to give positive comments on students' English pronunciation and oral performance. Once identifying students with negative pronunciation self-concepts, they should take actions to empower their students through external interventions, such as raising students' awareness of phonology learning strategies, which can improve their pronunciation, and later their higher levels of phonological achievement can facilitate subsequent development of their self-concepts. In this way, improved self-concepts will lead to better achievement and improved achievement will lead to better self-concepts. With self-concepts and achievement mutually reinforcing each other, a virtuous cycle is created. On the other hand, students can be organized to share personal experiences and offer mutual assistance on English phonology learning. Alrajhi and Aldhafri (2015) investigated a peer tutoring program implemented with 125 Omani university students, and attested to its positive influence on English self-concept. The close tutor-tutee relationship was characterized by sharing the same English learning experiences, being of a similar age, and offering encouragement. This enabled students to develop a positive self-concept related to their English learning.

In addition to AoLE and EPSC, Gen, AOEU, EoFL and MEPL were also identified as significant predictors. They could, to some extent, predict the EPA of the whole sample of university students in the Chinese EFL context. Gen and AOEU were found to predict the EPA of first-year and third-year English majors. Conversely, MEPL played an explanatory role in the case of first-year non-English majors. Since this study is the first to examine the impact of age and other extra-linguistic factors on the EPA of Chinese university students, whether Gen, AOEU, EoFL and MEPL are persistent predictors of EFL phonological attainment needs to be verified by followup studies.

\section{Conclusion}

\section{Major Findings}

This study examines the effects of age of learning English together with ten other extra-linguistic factors on the ultimate English phonological attainment of 318 university students as a whole and across three cohorts in the Chinese EFL context. To recap, the age of learning English could only predict the phonological attainment of first-year non-English majors, explaining $4 \%$ of its variance. Compared with the age factor, English pronunciation self-concept is a much more robust predictor for the whole sample and across the three cohorts, explaining 
11.8-25.1\% of the variance in their EFL phonological scores. Additionally, gender, amount of oral English use, experiences with other foreign languages, and motivation for English phonology learning can be predictive to a certain degree, either for the whole sample or for different cohorts of students.

The question of what age is optimal to start EFL learning has vast significance. With evidence of the effect of an earlier start on the EFL phonological attainment of university non-English majors being quite weak, adding in the unavailability of adequately trained English teachers in most regions of China, EFL education earlier than the third grade of primary school seems unnecessary, and the role of the age factor should not be exaggerated.

\section{Implications}

The findings of this study have several implications for ESL/EFL educators, researchers and teachers alike. Theoretically, the study contributes to the long-standing debate over the viability of the CPH as a physiological threshold beyond which mastery of a new phonological system is usually impossible by adding empirical evidence from the EFL context of China, which boasts the largest number of EFL learners, to the existing agerelated literature. Prior studies have predominantly been carried out with immigrant populations, so it is unclear whether findings from naturalistic ESL contexts can apply to instructional EFL settings. This study assesses the age effect on Chinese EFL learners' ultimate phonological attainment, its findings are conducive to enriching the theory of L2 phonological acquisition.

Methodologically speaking, this study investigates age and ten other factors via a multi-factorial approach, an approach rarely used in age-related L2 phonology research. As the age factor may co-vary with other factors likely to affect L2 phonology, research into multiple factors can compare the individual contribution and relative importance of every factor so as to explore the systemic complexity of phonology learning. Following this approach, the study finds that the effect of age of learning English in the EFL context is not as great as in the ESL context, while English pronunciation self-concept is a more constant and potent predictor. For EFL phonological attainment to grow, it makes more sense to cultivate EFL learners' positive English pronunciation self-concepts than to lower their ages of learning English.

At the practical level, a deeper understanding of the age factor in relation to EFL phonology can inform decisions on early language educational planning. The main obstacle to implementing early English education in China is the lack of qualified teachers at the primary school and preschool levels. The English proficiency of many teachers is insufficient to provide learners with rich input in the form of standard pronunciation needed for successful EFL phonology learning. To overcome this obstacle, launching pre-service and in-service educational programs to train primary school English teachers in phonology and familiar with phonology teaching methods needs to be put on the agenda. The government should make systematic efforts to enhance English teachers' professional skills and mandate their benchmarking. In China, teaching English has become a private business outside regular schools. Parents who can afford the tuition are arranging for private out-of-school English classes for their children. Judging from our study, the myth of 'younger is better' seems inapplicable to formal EFL instructional contexts; there is actually no need to plan children's English study before the third grade of primary school. Early English educational planning should be cautiously made within families, especially in regions where an absence of qualified teachers is more of a problem and language resources are less accessible.

\section{Suggestions for Future Research}

Motivated by the popular view of 'younger is better', EFL education has been implemented at primary school across Europe, but the long-term effects of an early start have not received ample scientific scrutiny in Europe (Jaekel et al., 2017). Likewise, the superiority of English in Asian countries has manifested itself in language policy and national curricula, yet the reasonability of early English education is calling for empirical experimentation rather than blind implementation. The present study takes the first step to examine the age effect in the Chinese EFL context by adopting a multi-factorial approach, thereby gaining some important findings never reported before. Undeniably, its sample was on of convenience, which may be seen as a limitation of the study. It is thus recommended to conduct further research where larger numbers of participants randomly sampled from different majors and grades are involved. Additionally, several other extra-linguistic factors surrounding L2 phonological acquisition including learning styles and amount of input, among others, also merit consideration in the future. Regarding the generalizability of our findings, it is advisable to undertake further research using the identical research design but implemented in other EFL contexts, which will benefit from a comprehensive 


\section{ZHENGWEI PEI, KERONG QIN}

multi-factorial approach, combining age with other relevant factors in the way the present study did.

\section{Acknowledgements}

This study was supported by the Fundamental Research Funds for the Central Universities, under Grant SKCX2016004; and Jiangsu Social Sciences Funds under Grant 13YYB008, China.

\section{References}

Abrahamsson, N. (2012). Age of onset and nativelike L2 ultimate attainment of morphosyntactic and phonetic intuition. Studies in Second Language Acquisition, 34(2), 187-214. doi: 10.1017/S0272263112000022

Alrajhi, M. N., \& Aldhafri, S. S. (2015). Peer tutoring effects on Omani students' English self-concept. International Education Studies, 8(6), 184-193. doi:10.5539/ies.v8n6p184

Birdsong, D. (2006). Age and second language acquisition and processing: A selective overview. Language Learning, 56, 9-49. doi: https://doi.org/10.1111/j.1467-9922.2006.00353.x

Chen, Z. G. (1983). Item analysis of Eysenck Personality Questionnaire tested in Beijing-district. Acta Psychologica Sinica, 15(2), 211-218.

De Vaus, D. (2002). Analyzing social science data. London, UK: Sage Public.

Dörnyei, Z., \& Schmidt, R. (2001). Motivation and second language acquisition. Manoa, HI: University of Hawaii Press.

Doughty, C. J., \& Long, M. H. (2003). The handbook of second language acquisition. Oxford, UK: Blackwell.

Elliott, A. R. (1995). Field independence/dependence, hemispheric specialization, and attitude in relation to pronunciation accuracy in Spanish as a foreign language. Modern Language Journal, 79(3), 356-371.

Festinger, L. (1954). A theory of social comparison processes. Human Relations, 7, 117-140.

Gui, S. C. (2012). Say 'no' to the fashion of starting to teach English in the kindergarten. Foreign Languages in China, 9(1), 41-47.

Hu, G. W. (2005). English language education in China: Policies, progress, and problems. Language Policy, 4(1), 5-24. doi: $10.2167 /$ jmmd600.0

Jacobsen, M., \& Imhoof, M. (1974). Predicting success in learning a second language. Modern Language Journal, $58,329-336$.

Jaekel, N., Schurig, M., Florian, M., \& Ritter, M. (2017). From early starters to late finishers? A longitudinal study of early foreign language learning in school. Language Learning, 67(3), 631-664. doi: https://doi.org/10.1111/ lang. 12242

Jedynak, M. (2013). Affectivity in learning L2 phonology/phonetics - The role of self-concept in successful acquisition of English pronunciation. In D. Gabryś-Barker \& J. Bielska (Eds.), The affective dimension in second language acquisition (pp. 60-73). Bristol, Buffalo, Toronto, Canada: Multilingual Matters.

King, R. B., \& McInerney, D. M. (2014). Mapping changes in students' English and Math self-concepts: Alatent growth model study. Educational Psychology, 34(5), 581-597. doi: http://dx.doi.org/10.1080/01443410.2014. 909009

Kline, R. B. (2005). Principles and practice of structural equation modeling. New York, NY: The Guilford Press.

Krashen, S., Long, M., \& Scarcella, R. (1979). Age, rate, and eventual attainment in second language acquisition. TESOL Quarterly, 13, 573-582.

Larson-Hall, J. (2008). Weighing the benefits of studying a foreign language at a younger starting age in a minimal input situation. Second Language Research, 24(1), 35-63. doi: https://doi.org/10.1177/0267658307082981

Larson-Hall, J. (2010). A guide to doing statistics in second language research using SPSS. New York, NY: Routledge.

Lenneberg, E. H. (1967). Biological foundations of language. New York, NY: Wiley.

Long, M. H. (2007). Problems in SLA. Mahwah, NJ: Lawrence Erlbaum Associates.

Luo, H., \& Zhang, W. Z. (2006). Analysis of English pronunciation errors made by college students. China University Teaching, 7, 60-61.

Marsh, H. W., \& Shavelson, R. J. (1985). Self-concept: Its multifaceted, hierarchical structure. Educational Psychologist, 20(3), 107-123.

Mercer, S. (2011). Language learner self-concept: Complexity, continuity and change. System, 39(3), 335-346. 
doi: 10.1016/j.system.2011.07.006

Mercer, S. (2012). The dynamic nature of a tertiary learner's foreign language self-concepts. In M. Pawlak (Ed.), New perspectives on individual differences in language learning and teaching (pp. 201-215). Berlin, Germany: Springer Verlag.

Moyer, A. (2014). Exceptional outcomes in L2 phonology: The critical factors of learner engagement and selfregulation. Applied Linguistics, 35(4), 418-440. doi: https://doi.org/10.1093/applin/amu012

$\mathrm{Mu}, \mathrm{K}$. J. (2006). The relationship between English self-concept and English pronunciation of Chinese freshmen majoring in English (Unpublished Master's thesis), Anhui University, Hefei, China.

Muñoz, C. (2008). Age-related differences in foreign language learning: Revisiting the empirical evidence. International Review of Applied Linguistics in Language Teaching, 46, 197-220. doi: 10.1515/IRAL.2008.009

Pei, Z. W. (2010). Musical aptitude and English phonological skills: An investigation of tertiary-level EFL learners in China (Unpublished PhD thesis). Nanjing University, Jiangsu Sheng, China.

Pei, Z. W. (2012). English phonological competence of non-English majors and its factors. Journal of Southeast University, 14(6), 116-123.

Peterson, S. S. (2000). Pronunciation learning strategies: A first look. Retrieved from http://files.eric.ed.gov/ fulltext/ED450599.pdf

Piske, T., MacKay, I. R. A., \& Flege, J. E. (2001). Factors affecting degree of foreign accent in an L2: A review. Journal of Phonetics, 29(2), 191-215. doi: 10.006/jpho.2001.0134

Qian, M. Y., Wu, G. C., Zhu, R. C., \& Zhang, S. (2000). Development of the revised Eysenck Personality Questionnaire Short Scale for Chinese (EPQ-RSC). Acta Psychologica Sinica, 32(3), 317-323.

Sheppard, C., Hayashi, C., \& Ohmori, A. (2007). Factors accounting for attainment in foreign language phonological competence. Proceedings of 16International Congress of Phonetic Sciences, 1597-1600.

Singleton, D., \& Leśniewska, J. (2012). Age and SLA: Research highways and bye-ways. In M. Pawlak (Ed.), New perspectives on individual differences in language learning and teaching (pp. 97-113). Berlin, Germany: Springer Verlag.

Singleton, D., \& Muñoz, C. (2011). Around and beyond the critical period hypothesis. In E. Hinkel (Ed.), Handbook of research in second language teaching and learning (pp. 407-425). London, UK: Routledge.

Singleton, D., \& Skrzypek, A. (2014). Age and the classroom learning of additional languages. In M. Pawlak, J. Bielak \& A. Mystkowska-Wiertelak (Eds.), Classroom-oriented research: Achievements and challenges (pp. 3-13). Heidelberg, Germany: Springer.

Tang, X., Zhang, S., Li, Y., \& Zhao, M. (2013). Study on correlation of English pronunciation self-concept to English learning. English Language Teaching, 6(4), 74-79. doi: 10.5539/elt.v6n4p74

Thompson, I. (1991). Foreign accents revisited: The English pronunciation of Russian immigrants. Language Learning, 41(2), 177-204.

Wang, C. M. (2004). English pronunciation self-concept and actual pronunciation. Foreign Language World, 5, 62-67.

Yoleri, S., \& Yatağanbaba, E. (2013). Current educational policies and trends in teaching English to young learners around the globe. Mediterranean Journal of Educational Research, 14a, 774-779.

Zhang, D. B. (2012). Chinese primary school English curriculum reform. In J. Ruan \& C. B. Leung (Eds.), Perspectives on teaching and learning English literacy in China (pp. 67-83). Dordrecht, the Netherlands: Springer.

Zhang, G. L. (1988). A handbook of English pronunciation exercises for first-year college students. Beijing, China: Foreign Language Teaching and Research Press. 


\section{Appendix 1}

\section{Chinese and English Versions of the Questionnaire}

\section{英语语音学习调查问卷}

姓名 性别 年龄 专业 年级 学校

本问卷旨在了解高校大学生英语语音学习的相关情况, 请根据自身实际情况作答。您提供的信息是一项研究的重 要依据, 调查组会予以保密, 感谢合作!

第一部分: 请将回答填写在横线上或勾选相应的答案。

1. 你目前的听力状况:

1）正常 2) 不正常

2. 你从几岁开始接触并学习英语？（请填实足年龄） 岁

3. 你目前每周讲英语的总时间大约为: 小时

4. 参加本研究前, 你在校内外接受英语语音训练的时间大约为（请将小学、中学和大学阶段都估算在内）: 小时

5. 除英语外, 你还学过其他外语吗?

1) 是 2) 否

6. 你模仿不熟悉语音（如外语、其他方言）的能力怎样?

1) 很差

2) 较差

1) 很差

2) 较差

1) 很差

2) 较差

3) 一般

4) 较强

3) 一般

4) 较强

3) 一般

4) 较强

5）很强

8. 你的歌唱能力怎样?

第二部分：请仔细阅读题项，根据你的实际情况勾选答案，肯定回答选 $Y$, 否定回答选 $N$ 。

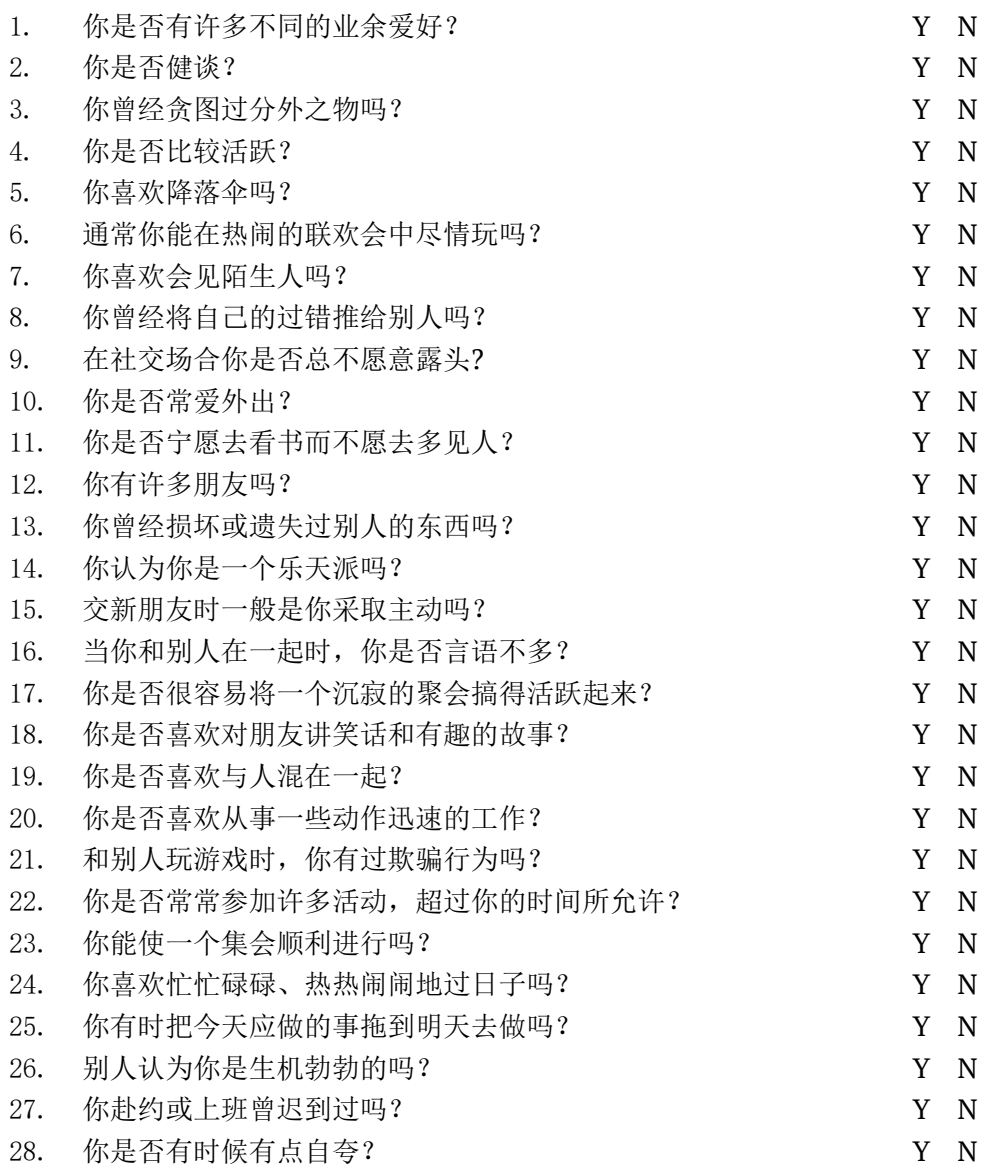


第三部分: 下面各题项描述了对英语发音的自我认知和评价, 请仔细阅读题项, 思考该描述在多大程度上符合你 的实际情况, 并在合适的数字上打勾。

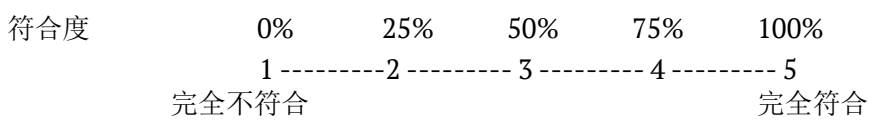
1. 我念英语很好听。
12345
2. 我常听别人说我的英语发音很好听。
12345
3. 我擅长学习英语发音。
12345
4. 我的英语发音不比其他同学差。
12345
5. 我的英语发音很糟糕。
12345
6. 我发音不好, 特别怕在课堂上说英语。
12345
7. 我学英语发音不比其他同学差。
12345
8. 我感觉自己的英语发音不是很好听。
12345

第四部分: 下面各题项描述了对英语语音学习的看法、态度、愿望和努力。请仔细阅读题项, 思考该描述在多大 程度上符合你的实际情况, 并在合适的数字上打勾。

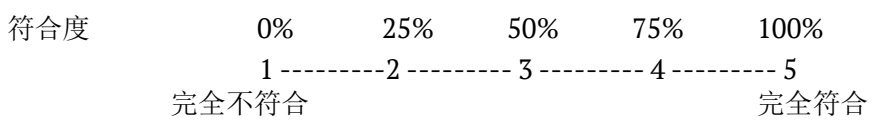

1. 我会为了英语发音更完美而努力。

2. 我希望自己的发音像英语本族语者或英语教师那样自然流畅。

12345

3. 会讲英语对在国内就业有利。

4. 如果有机会的话, 我希望出国学习英语。

12345

. 如果有机会的话, 我希望出国学习英语。

$\begin{array}{lllll}1 & 2 & 3 & 4 & 5\end{array}$

我今后想从事使用英语的工作。

12345

6. 我想和英语本族语者一起学习或工作。

12345

7. 掌握发音在英语学习中极其重要。

$\begin{array}{lllll}12 & 3 & 4 & 5\end{array}$

8. 我希望将来自己的英语能讲得正确而自然。

12345

9. 我希望增加英语语音课程和获得发音指导的机会。

$\begin{array}{lllll}1 & 2 & 3 & 4 & 5\end{array}$

10. 我对英语或英语文化很感兴趣。

$\begin{array}{lllll}1 & 2 & 3 & 4 & 5\end{array}$

11. 我会毫不解急地以正确的发音为目标努力学习。

$\begin{array}{lllll}12 & 3 & 4 & 5\end{array}$

12. 我想和英语本族语者成为朋友。

$\begin{array}{lllll}1 & 2 & 3 & 4 & 5\end{array}$

13. 我想用英语和来自其他国家的人交流。

12345

14. 在与其他英语学习者或英语本族语者用英语交谈时, 我希望自己的发音不被人笑话。

15. 我喜欢学习英语。

第五部分: 下面各题项描述了英语语音学习的具体做法和策略。请仔细阅读题项, 思考该描述在多大程度上符合 你的实际情况，并在合适的数字上打勾。

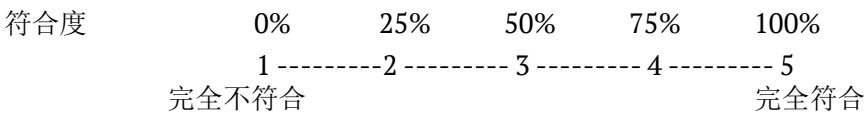

1. 自编歌曲或节奏来记忆单词的发音。

2. 按音标或自己的代码来记忆发音, 如ponderous（胖得要死）。

3. 回忆教师的发音。

4. 回忆并模仿老师发音时的口型。

5. 说英语时会注意单词的发音。

6. 为了发音准确, 放慢语速。

7. 关注或尝试不同的英语口音, 如英式发音、印度英语发音等。

8. 开口说英语之前先默读每个单词。

9. 模仿英语本族语者或教师的发音。

$\begin{array}{lllll}1 & 2 & 3 & 4 & 5\end{array}$

10. 用英语大声地自我操练发音。 
11. 独自不出声地练习说英语。

12. 发音时注意自己的唇型。

13. 听别人说英语时关注单词的发音。

14. 说英语时有意识地避免汉语发音的影响, 如n, 1不分。

12345

15. 为好玩用汉语发音模仿英语的单词发音, 如thank you发成“三克油”。

12345

16. 不停地重复难发音的单词。

$\begin{array}{lllll}12 & 3 & 4 & 5\end{array}$

17. 用单词抽认卡来练习发音。

$\begin{array}{lllll}1 & 2 & 3 & 4 & 5\end{array}$

18. 一开始慢速练习发音, 熟悉后加快语速。

$\begin{array}{lllll}1 & 2 & 3 & 4 & 5\end{array}$

19. 记忆并练习英语词组的发音。

$\begin{array}{lllll}12 & 34 & 4\end{array}$

20. 跟读本族语者或教师来练习发音。

$\begin{array}{lllll}12 & 3 & 4 & 5\end{array}$

21. 跟读英语磁带、英文电视节目或电影来练习发音。

12345

22. 默读或大声朗读以操练发音。

12345

23. 通过做相关练习来学习英语发音。

$\begin{array}{lllll}12 & 3 & 4 & 5\end{array}$

24. 先单独练习单词发音, 然后将单词置于语境中练习。

12345

25. 自己总结发音规则, 并加以运用。

12345

26. 注意汉语和英语发音的不同之处。

12345

27. 系统地学习英语语音知识。

12345

28. 阅读英语语音方面的书籍。

12345

29 . 设立目标集中听取和练习某些发音。

12345

30. 按照确立的发音目标循序渐进, 逐渐改变、纠正发音。

$\begin{array}{lllll}1 & 2 & 3 & 4 & 5\end{array}$

31. 准备英语口头汇报时将难发的音用记号笔或画线等方法突显表示。

$\begin{array}{lllll}12345 & \end{array}$

32. 录下自己的发音重复听。

12345

33. 用幽默的方式掩饰发错音时的尴尤。

$\begin{array}{lllll}123 & 34\end{array}$

34. 请求他人帮助纠正自己的发音。

$\begin{array}{lllll}1234 & 34\end{array}$

35. 请求他人示范发音。

12345

36. 与其他人一起学习英语发音。

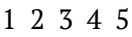

37. 指导其他人的英语发音。

12345 


\section{Questionnaire on English Phonology Learning}

Name Gender Age Major Grade University

This questionnaire is administered for the purpose of understanding how university students in China learn English phonology. Please respond to it according to your own situation. The information you provide serves as crucial data of a study, and will be kept confidential. Thank you for your cooperation!

Part One: Give your answers or select the choices that best represent yourself.

1. How is your hearing status?

1) normal 2) abnormal

2. When did you begin to learn English? At the age of

3. About how many hours do you spend in orally using English in and outside of English class per week at the time of taking part in this study? _ hours.

4. Roughly how long have you received English phonological training from regular classes at school or/and extracurricular programs before participating in the study? __ hours.

5. Have you learned or picked up foreign languages other than English?

1) Yes 2) No

6. How is your aptitude for orally mimicking unfamiliar sounds (e.g., foreign languages or dialects)?

7. How is your sense of music?

1) extremely weak 2) relatively weak 3) average 4) relatively strong 5) extremely strong

8. How is your singing ability?

1) extremely weak 2) relatively weak 3) average 4) relatively strong 5) extremely strong

1) extremely weak 2) relatively weak 3) average 4) relatively strong 5) extremely strong

Part Two: Read the items below carefully. Put a tick on Y (Yes) if the item is applicable to you and on N (No) if not.

1. Do you have many hobbies?

$\mathrm{Y} \quad \mathrm{N}$

2. Are you talkative?

$\mathrm{Y} \quad \mathrm{N}$

3. Have you ever coveted anything belonging to someone else?

$\mathrm{Y} \quad \mathrm{N}$

4. Are you socially active?

$\mathrm{Y} \quad \mathrm{N}$

5. Do you like parachutes?

$\mathrm{Y} \quad \mathrm{N}$

6. Can you usually enjoy yourself at a noisy get-together? $\quad \mathrm{Y} N$

7. Do you like meeting strangers? $\quad \mathrm{Y} N$

8. Have you ever blamed others for your mistakes? $\quad \mathrm{Y} N$

9. Do you always avoid showing up in social situations? $\quad \mathrm{Y} N$

10.Do you like going out a lot? $\quad \mathrm{Y} \mathrm{N}$

11.Would you rather read books than meet people? $\quad \mathrm{Y}$ N

12.Do you have many friends? $\quad \mathrm{Y} \mathrm{N}$

13. Have you ever damaged or lost anything belonging to some else? $\quad \mathrm{Y} \quad \mathrm{N}$

14.Do you think of yourself as an optimist? $\quad \mathrm{Y} \mathrm{N}$

15.Do you usually take the initiative when making new friends? $\quad \mathrm{Y} N$

16.Do you always keep silent when you are together with others? $\quad \mathrm{Y} N$

17. Can you easily liven up a quiet party? $\quad \mathrm{Y}$ N

18.Do you like telling jokes and funny stories to your friends? $\quad \mathrm{Y}$ N

19.Do you like hanging out with others? $\quad \mathrm{Y}$ N

20.Do you enjoy doing some jobs requiring quick movements? $\quad \mathrm{Y} \quad \mathrm{N}$

21. Have you ever cheated while playing games with others? $\quad \mathrm{Y} N$

22.Do you often take part in more activities than your time allows? $\quad \mathrm{Y} N$

23. Can you make a meeting go smoothly? $\quad \mathrm{Y} N$

24.Do you enjoy the hustle and bustle of life? $\quad \mathrm{Y} \mathrm{N}$

25.Do you sometimes put off till tomorrow what you should do today? $\quad \mathrm{Y}$ N

26.Do other people think you are vigorous? $\quad \mathrm{Y} \quad \mathrm{N}$

27. Have you ever been late for an appointment or work? $\quad \mathrm{Y} \quad \mathrm{N}$

28.Do you sometimes brag a little bit? $\quad \mathrm{Y} N$ 
Part Three: The items below describe your self-conception and assessment of your English pronunciation. Read them carefully and consider to what degree these descriptions are applicable to you before ticking the most appropriate numbers.

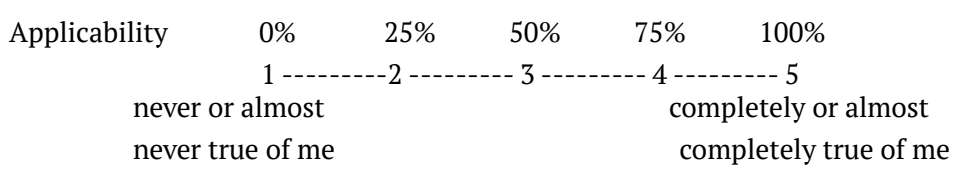

1. My English pronunciation is pleasant to others' ears.

12345

2. I often hear others say my pronunciation is nice.

12345

3. I'm good at studying English pronunciation.

123345

4. My pronunciation is not worse than that of my classmates.

12345

5. My English pronunciation is poor.

12345

6. I'm afraid of speaking English in class because of my poor pronunciation.

12345

7. I study English pronunciation as well as my classmates do.

12345

8. I feel my pronunciation is not very pleasant to others' ears.

Part Four: The items below describe your perceptions, attitudes, aspirations, and effort in relation to English phonology learning. Read them carefully and consider to what degree these descriptions are applicable to you before ticking the appropriate numbers.

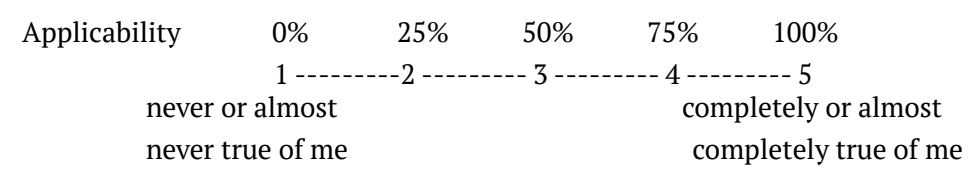

1. I will study hard to perfect my English pronunciation.

2. I want to sound natural and fluent like a native speaker or an English teacher.

3. Being able to speak English helps my job hunting.

$\begin{array}{lllll}1 & 2 & 3 & 4 & 5\end{array}$

4. I hope to study English abroad if there is a chance.

12345

5. I want to be engaged in using English in my future job.

$\begin{array}{lllll}1 & 2 & 3 & 4 & 5\end{array}$

6. I want to study or work together with native speakers.

12345

7. A mastery of good pronunciation is important in English study.

12345

8. I hope to speak English properly and naturally in the future.

9. I hope to increase the chances of taking courses and obtaining guidance on English phonology.

10. I take a keen interest in English and the cultures of English-speaking communities.

12345

11. I will never slack off in studying hard with the goal of correct pronunciation.

12345

12. I want to make friends with native speakers.

13. I want to communicate with foreigners in English.

14. I hope not to be laughed at for my pronunciation when talking with other English learners or native speakers.

15. I enjoy studying English.

Part Five: The items below describe the strategies you may use to study English phonology. Read them carefully and consider to what degree these descriptions are applicable to you before ticking the appropriate numbers.

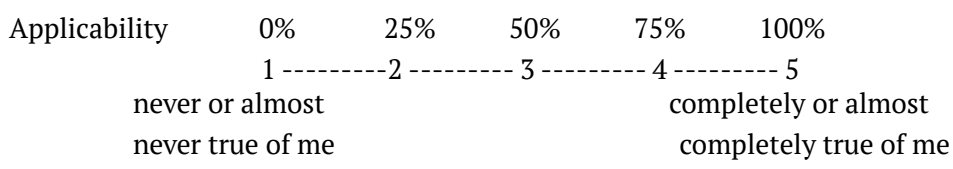

1. I make up songs or rhythms to remember how to pronounce words.

2. I use phonetic symbols or my own codes to remember pronunciation. 
3. I recall how a teacher pronounced something.

4. I recall and imitate a teacher's mouth movements.

5. I concentrate on word pronunciation while speaking English.

6. I speak slowly to get the pronunciation right.

7. I notice or try out different English accents, e.g., British English, Indian English.

12345

8. I mentally rehearse how to say every word before speaking English.

$\begin{array}{lllll}1 & 2 & 3 & 4 & 5\end{array}$

9. I imitate a native speaker or an English teacher.

12345

$\begin{array}{lllll}12 & 3 & 4 & 5\end{array}$

10. I practise pronunciation aloud in English.

11. I practise speaking English silently by myself.

12. I notice my lips while pronouncing something.

12345

13. I notice how words are pronounced while listening to others speak English.

$\begin{array}{lllll}12 & 3 & 4 & 5\end{array}$

14. I avoid the influence of Chinese pronunciation when speaking English.

12345

15. I imitate English words in Chinese for fun.

16. I pronounce a difficult word over and again.

17. I practise word pronunciation using flash cards.

18. I practise saying words slowly at first and then faster.

19. I memorize and practise how to pronounce English phrases.

12345

$\begin{array}{lllll}1 & 2 & 3 & 4 & 5\end{array}$

20. I repeat aloud after a native speaker or teacher.

21. I repeat English from tapes, TV programs or movies aloud.

22. I read silently or aloud to practise pronunciation.

23. I do exercises to acquire English sounds.

24. I practise sounds first in isolation and then in context.

25. I summarize pronunciation rules and apply them.

26. I notice the contrasts between Chinese and English pronunciations.

27. I acquire a systematic knowledge of English phonetics.

28. I read reference books about English phonology.

29. I set goals to listen to and practise certain English sounds.

30. I improve pronunciation step by step according to established goals.

31. I prepare for an oral presentation by highlighting hard-to-pronounce words.

32. I record and listen to my own pronunciation.

33. I use a sense of humor about mispronunciations.

34. I ask someone else to correct my pronunciation.

35. I ask someone else to pronounce something.

36. I study pronunciation with someone else.

12345

37. I teach someone else to pronounce something. 


\section{Appendix 2}

\section{Correlation matrix for regression modeling $(n=318)$}

Table 1

Coefficients indicating the interrelationships among Predictors and EPA

\begin{tabular}{|c|c|c|c|c|c|c|c|c|c|c|c|c|}
\hline & AoLE & $\mathrm{AOM}$ & $\mathrm{MuAb}$ & $\mathrm{AOEU}$ & Pers & EPSC & MEPL & SEPL & AEPT & Gen & EoFL & EPA \\
\hline AoLE & 1 & & & & & & & & & & & \\
\hline $\mathrm{AOM}$ & $-.047^{\mathrm{a}}$ & 1 & & & & & & & & & & \\
\hline $\mathrm{MuAb}$ & $-.216^{* * k+k a}$ & $.362^{* * * * * a} a$ & 1 & & & & & & & & & \\
\hline AOEU & $-.128^{* a}$ & $.084^{\mathrm{a}}$ & $.114^{* a}$ & 1 & & & & & & & & \\
\hline Pers & $-.085^{\mathrm{a}}$ & $.050^{\mathrm{a}}$ & $.108^{\mathrm{a}}$ & $-.020^{\mathrm{a}}$ & 1 & & & & & & & \\
\hline EPSC & $-.121^{* a}$ & $.433^{* * * * a} \mathrm{a}$ & $.427^{* * * * \mathrm{*} a}$ & $.033^{a}$ & $.124^{* a}$ & 1 & & & & & & \\
\hline MEPL & $-.018^{a}$ & $.147^{* * \mathrm{a}_{\mathrm{a}}}$ & $.173^{* * a}$ & $.251^{* * * * a}$ & $-.015^{\mathrm{a}}$ & $.324^{* * * * * a}$ & 1 & & & & & \\
\hline SEPL & $-.033^{a}$ & $.079^{a}$ & $.257^{* k_{k} * a}$ & 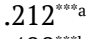 & $.096^{\mathrm{a}}$ & $.307^{* * * k^{*}} \mathrm{a}$ & 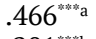 & 1 & & & & \\
\hline AEPT & $-.141^{* b}$ & $.047^{\mathrm{b}}$ & $.127^{* \mathrm{~b}}$ & $.400^{* * * \mathrm{~b}}$ & $.063^{\mathrm{b}}$ & $.194^{* * * \mathrm{~b} b}$ & $.201^{* * * \mathrm{~b}}$ & $.255^{* * * \mathrm{~b}}$ & 1 & & & \\
\hline Gen & $-.123^{*} \mathrm{c}$ & $.001^{\mathrm{d}}$ & $.006^{* d}$ & 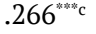 & $.008^{c}$ & $.003^{d}$ & $.004^{\mathrm{d}}$ & $.003^{\mathrm{d}}$ & $.161^{* * * *} \mathrm{c}$ & 1 & & \\
\hline EoFL & $.061^{\mathrm{c}}$ & $.001^{\mathrm{d}}$ & $.002^{\mathrm{d}}$ & $.159^{* * * *} \mathrm{c}$ & $-.020^{c}$ & $.007^{* * * * \mathrm{~d}}$ & $.002^{\mathrm{d}}$ & $.003^{\mathrm{d}}$ & $.077^{\mathrm{c}}$ & $.070^{* * * * \pi} \mathrm{d}$ & 1 & \\
\hline EPA & $-.146^{* * \mathrm{*a}}$ & $.224^{* * *+a}$ & $.294^{* * *+a}$ & $.208^{* * * * a}$ & $.003^{a}$ & $.483^{* * * k^{*} \mathrm{a}}$ & $.319^{* * * * a}$ & $.263^{* * * \mathrm{a} a}$ & $.292^{* * * * \mathrm{~b} b}$ & $.253^{* * * * \mathrm{c}} \mathrm{c}$ & $.240^{* * * k_{c}}$ & 1 \\
\hline
\end{tabular}

Note. ${ }^{*} \mathrm{p}<.05,{ }^{* *} \mathrm{p}<.01,{ }^{* * *} \mathrm{p}<.001$ (2-tailed). Correlation computed as a Pearson's $\mathrm{r},{ }^{\mathrm{b}}$ Spearman's rho, ${ }^{\mathrm{c}}$ point-biserial $\mathrm{r}_{\mathrm{pb}}$, ${ }^{\mathrm{d}}$ Goodman and Kruskal's $\tau$

AoLE $=$ age of learning English, $\mathrm{AOM}=$ aptitude for oral mimicry, MuAb = musical ability, $\mathrm{AOEU}=$ amount of oral English use, Pers = personality, EPSC = English pronunciation self-concept, MEPL = motivation for English phonology learning, SEPL = strategies for English phonology learning, AEPT = amount of English phonological training, Gen = gender, EoFL = experiences with other foreign languages, EPA = EFL phonological attainment 